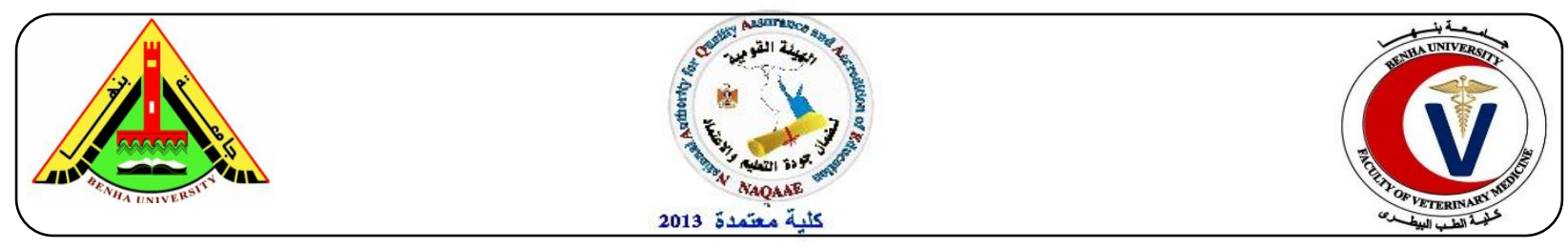

\title{
Food Poisoning Bacteria in Ready to Eat Meat and Chicken Meat Products
}

\author{
Saad M. Saad ${ }^{\mathrm{a}}$, Dalia F. Khater ${ }^{\mathrm{b}}$ and Sara M. Zaki . \\ ${ }^{a}$ Department of Food Control, Faculty of Veterinary Medicine, Benha University, Egypt \\ ${ }^{b}$ Food Hygiene Dept., Tanta Lab., Animal Health Research Institute \\ ${ }^{c}$ Food Hygiene Dept., Tanta University Hospitals
}

\section{A B S T R A C T}

Contamination of ready to eat foods sold by street vendors, restaurants and markets premises rendering has become a global health problem. The present study was designed to examine bacteriologically some ready to eat products (beef luncheon, chicken luncheon, grilled kofta and grilled chicken) for (E. coli, S. aureus, Sallmonellae and B. cereus.) The incidence of E.coli was high in beef luncheon and chicken luncheon by $24 \%, S$. aureus was high in grilled chicken by $36 \%$ and $B$. cereus was high in grilled kofta by $24 \%$. Salmonella spp were not be detected in all examined samples. The presence of these microorganisms in ready to eat food samples makes them unfit for human consumption. Generally, the application and implementation of Hazard Analysis and Critical Control Point (HACCP) System as a hazards control system must be done in meat serving establishments.

Key words: Ready to eat food, B. cereus, Salmonella spp, S. aureus, E. coli.

$$
\text { (http://www.bvmj.bu.edu.eg) }
$$

(bvmj, 35(1): 301-310, Sept., 2018)

\section{INTRODUCTION:}

Meat and chicken meat products are very popular food in Egypt as well as throughout the world. No wonder since they are delicious as considered as good and cheap sources of protein characterized by good flavor and easily digested. The increase of human population and the great progress of various aspects of life make the consumer to use meat products in different forms for their ease preparation such as luncheon.

The modern technology in different fields gives chance for the processors to produce new products of different shapes, easily handled, stored and rapidly used. The need for meat and chicken meat products such as luncheon has many tasks, including, new flavor, preservation, low fat content and low calories. Thus, the quality of raw material as well as the additives and final product is very important for the characterization of the final products. Therefore, using of low quality ingredients in the processing yields low quality chicken and meat products.

Contamination of meat and chicken meat products may occur throughout initial processing, packaging and storage until the product is sufficiently cooked and consumed. These products can harbor multiple types of pathogenic bacteria capable of causing human diseases. These types of bacteria can include E. coli, S. aureus, B. cereus and Salmonella spp. which are of the major concern (Waldroup, 1996). 
Actually, E. coli is an important organism involved in food-borne disease, it is considered as a good indicator of possible fecal contamination (Synge, 2000).

Presence of $S$. aureus in food indicates bad hygienic conditions with great hazard which reflects the importance of isolation of such type of food borne pathogen It can cause different types of diseases and food poisoning outbreaks in human being (Hashim, 2003).

Bacillus cereus causes food spoilage and can produce two distinct types of toxin, which differ in the main symptoms induced in human. (Ehling Schulz et al., 2004; Schoeni and Lee wong, 2005 and Rajkovic et al., 2006).

Salmonella can persist on final raw products. Disease can result when these products are handled without good hygienic practices, not properly cooked and/or subjected to temperature abuse (Zhang et al., 2001). It is considered that the presence of Salmonella spp in products makes it unsafe for human consumption (Agunos, 2007and Muth, 2009).

Therefore, the present paper was applied to estimate the incidence of E. coli, S. aureus, Bacillus cereus and Salmonella spp in some ready to eat meat and chicken meat products.

\section{MATERIAL AND METHODS:}

\section{Collection of samples:}

A grand total of 100 random samples of grilled kofta, grilled chicken, beef luncheon and chicken luncheon (25 of each) were collected from different markets and restaurants at El-Gharbia governorate. The collected samples were subjected to bacteriological examinations to evaluate their safety and fitness for human consumption.

\section{Preparation of samples:}

The samples were prepared and examined according to the technique recommended by (APHA2001) as follow 25 grams of each sample were taken, cut into pieces, using sterile forceps and scissors and blended for 2 minutes in a sterile blender jar containing $225 \mathrm{ml}$ of sterile buffered peptone water $(1 \%)$.

\section{Isolation and identification:}

1. Isolation of E.coli was carried out according to (APHA 2001).

2. Morphological identification of $E$. coli was done according to (Macfaddin 2000).

3. Biochemical identification of $E$. coli was carried out according to (Kreig and Holt 1984).

4. Serological identification of E. coli was performed according to (Kok et al. 1996).

5. Isolation of Salmonella spp. was carried out according to (ISO 2002).

6. Isolation of $S$. aureus was carried out according to (FDA, b 2001).

7. Morphological identification of $S$. aureus was carried out according to (ICMSF 1996).

8. Biochemical identification of $S$. aureus was done according to (Maccfadin 2000).

9. Isolation of B. cereus was performed according to (Shinagawa 1990).

10. Biochemical identification of $B$. cereus was done according to (Baily and Scott 1998).

\section{RESULTS:}

The current results in table (1) indicated that incidence of $E$. coli in examined ready to eat food samples were $8 \%$ in grilled kofta, $8 \%$ in grilled chicken, $24 \%$ in beef luncheon and $24 \%$ in chicken luncheon. The highest incidence of E. coli was in grilled kofta and grilled chicken 
In table (2) results show incidence of $S$. aureus in examined ready to eat food samples were $32 \%$ in grilled kofta, 36\% grilled chicken, $28 \%$ beef luncheon and $20 \%$ in chicken luncheon. The highest incidence of $S$. aureus was in grilled chicken.

While the data presents in table (3) declared incidence of $S$. aureus in grilled kofta positive for coagulase activity 6 samples from 25 samples with incidence $24 \%$, while in grilled chicken recorded 7 positive from 25 samples with incidence $28 \%$, Also in beef luncheon 5 positive samples from 25 with incidence $20 \%$ and in chicken luncheon recorded 4 positive samples from 25 with incidence $16 \%$.

The results in table (4) showed that incidence of $B$. cereus in examined ready to eat food samples were $24 \%$ in grilled kofta, $12 \%$ in grilled chicken, $8 \%$ in beef luncheon and $4 \%$ in chicken luncheon, while the highest incidence was in grilled kofta.

Also, data obtained in the table (5) revealed that the isolated serotypes of pathogenic E.coli from the examined samples of grilled kofta were of O127: H6 (4\%) EHEC strains and O114: $\mathrm{H} 4$ (4\%).EHEC strains While in examined samples of grilled chicken O26: H11 (8\%) EHEC strains were identified. Moreover, O26: H11 (12\%) EHEC strains, O111: $\mathrm{H} 2$ (8\%) EHEC strains and O91:H21 (4\%) ETEC strains were identified in the examined samples of beef luncheon. While O111: H2 (12\%) EHEC strains, O26: H11 (8\%) EPEC strains and O44: H18 (4\%) EPEC strains were identified in the examined samples of chicken luncheon.

Table (1): Incidence of $E$. coli in the examined ready to eat meat and chicken product samples $(\mathrm{N}=25)$ and total number of samples (100)

\begin{tabular}{ccc}
\hline & \multicolumn{2}{c}{ Positive samples } \\
\cline { 2 - 3 } Product & No. & $\%$ \\
Grilled kofta & 2 & 8 \\
Grilled chicken & 2 & 8 \\
Beef luncheon & 6 & 24 \\
Chicken luncheon & 6 & 24 \\
\hline
\end{tabular}

Table (2): Incidence of Staph. aurues in the examined ready to eat meat and chicken product samples $(\mathrm{N}=25)$ and total number of samples (100)

\begin{tabular}{ccc}
\hline & \multicolumn{2}{c}{ Positive samples } \\
\cline { 2 - 3 } Product & No. & $\%$ \\
Grilled kofta & 8 & 32 \\
Grilled chicken & 9 & 36 \\
Beef luncheon & 7 & 28 \\
Chicken luncheon & 5 & 20 \\
\hline
\end{tabular}


Table (3): Incidence of coagulase positive staph. aureus isolated from meat and poultry product samples

\begin{tabular}{cccc}
\hline Samples & $\begin{array}{c}\text { Total } \\
\text { Staph.aureus } \\
\text { samples }\end{array}$ & $\begin{array}{c}\text { Coagulase positive } \\
\text { Staph.aureus } \\
\text { samples }\end{array}$ & $\%$ \\
\hline Grilled Kofta & 8 & 6 & $24 \%$ \\
Grilled chicken & 9 & 7 & $28 \%$ \\
Beef luncheon & 7 & 5 & $20 \%$ \\
Chicken luncheon & 5 & 4 & $16 \%$ \\
\hline
\end{tabular}

Table (4): Incidence of Bacillus cereus in the examined rready to eat meat and chicken product samples $(\mathrm{N}=25)$ and number of total samples (100)

\begin{tabular}{ccc}
\hline & \multicolumn{2}{c}{ Positive samples } \\
\cline { 2 - 3 } Product & No. & $\%$ \\
Grilled kofta & 6 & 24 \\
Grilled chicken & 3 & 12 \\
Beef luncheon & 2 & 8 \\
Chicken luncheon & 1 & 4 \\
\hline
\end{tabular}

Table (5): incidence and serotyping of $E$. coli isolated from meat and chicken product samples $(\mathrm{n}=25)$

\begin{tabular}{cccccccccc}
\hline & \multicolumn{1}{c}{ Grilled kofta } & Grilled chicken & Beef luncheon & \multicolumn{2}{c}{$\begin{array}{c}\text { Chicken } \\
\text { luncheon }\end{array}$} & Type \\
\hline E.coli strains & No. & $\%$ & No. & $\%$ & No. & $\%$ & No. & $\%$ & \\
$\mathrm{O}_{127:} \mathrm{H}_{6}$ & 1 & 4 & - & - & - & - & - & - & \\
$\mathrm{O}_{114:} \mathrm{H}_{4}$ & 1 & 4 & - & - & - & - & - & - & \\
$\mathrm{O}_{26}: \mathrm{H}_{11}$ & - & - & 2 & 8 & 3 & 12 & - & - & EHEC \\
$\mathrm{O}_{111}: \mathrm{H}_{2}$ & - & - & - & - & 2 & 8 & 3 & 12 & \\
$\mathrm{O}_{26}: \mathrm{H}_{11}$ & - & - & - & - & - & - & 2 & 8 & \\
$\mathrm{O}_{44}: \mathrm{H}_{18}$ & - & - & - & - & - & - & 1 & 4 & EPEC \\
$\mathrm{O}_{91}: \mathrm{H}_{21}$ & - & - & - & - & 1 & 4 & - & - & ETEC \\
Total & 2 & 8 & 2 & 8 & 6 & 24 & 6 & 24 & \\
& & & & & & & & &
\end{tabular}

\section{DISCUSSION:}

The safety and hygienic quality of meat products and chicken meat products are largely determined by the presence of microorganisms which are ubiquitous in nature. Thus, temperature is essential factor that plays a vital role in food safety. In other words, the primary purpose of sufficient cooking is to inhibit the growth of bacteria there by extending the shelf life of such food items (ICMSF, 1996). 
The current results in table (1) are in agreement with Saad et al. (2011) who isolated $10 \%$, Tavakoli and Riazipour (2008) who isolated $12.6 \%$ and lower than AlMutairi (2011) and Abdel Fattah (2014) who isolated $28 \%$ and $40 \%$, respectively $E$. coli in grilled kofta. These results are similar to Shanab (2014) who isolated $10 \%$ E.coli and Tavakoli and Riazipour (2008) who found 5\% E.coli in grilled chicken. While these results nearly similar to Shawish et al. (2014) who recorded $16 \%$ E.coli and Tarabees et al. (2015) who recorded $22.5 \%$ E.coli in beef luncheon.

As well as these results nearly to Sharaf and Sabra (2012) as they recorded 25\% E.coli in chicken luncheon.

The variation of results may be due to the differences in manufacture practices, handling from producers to consumers and the effectiveness of hygienic measures applied during production.

In general, E.coli is considered as an indicator of fecal contamination, besides, it may induce severe diarrhea in infants and young children as well as food poisoning and gastroenteritis among the adults (Synge, 2000).

The current results in table (2) are higher than these of Arab (2010), Sobieh (2014) and Hassan et al. (2016) who found $20 \%, 6.67 \%$ and $25 \%$ S. aureus in the examined samples of grilled kofta, respectively. As well as these results are lower than Ghanem (2009) and Morshedy et al. (2014) who recorded $46.6 \%$ and $65.6 \% \mathrm{~S}$ .aureus in the examined samples of grilled kofta, respectively. On the other side these results are nearly similar to Ali (2011) and Saad et al. (2011) who found $S$. aureus in grilled kofta by $40 \%$ and $35 \%$, respectively.
While, the results were higher than these of Hassanien (2004) who isolated $16 \%$ $S$. aureus from beef luncheon. Moreover, these results were higher than these found by Sharaf and Sabra (2012) as they isolated S. aureus from $10 \%$ of chicken luncheon and these results are lower than Khalifa and Abd ElShaheed (2005) who recorded $34.3 \% \quad S$. aureus in chicken luncheon.

The presence of $S$. aureus in food indicates poor hygiene and improper storage conditions (Gundogan et al., 2005). As well as $S$. aureus was frequently found on employees' gloves. Considering that S. aureus, which could cause foodborne intoxication, is carried in the nose, throat, skin and hair of humans (Le Loir et al., 2003).

Food handlers are the primary Source of $S$. aureus contamination in the processing plant. Most staphylococcal intoxications involving meat and chicken products are related to recontamination of cooked product by food handlers, followed by improper holding temperature.

The results in table (4) are nearly similar to those of Arab (2010) who recorded $26 \%$ B. cereus in grilled kofta. While, the results of beef luncheon are lower than result of Abostate et al. (2006) who recorded $60 \%$ and Ibrahim et al. (2014) who found 35\% B. cereus in beef luncheon. Moreover, the results of chicken luncheon are lower than results of Abostate et al. (2006) who isolated $53 \%$ and Hashim (2003) who isolated $42.3 \%$ of $B$. cereus in chicken luncheon.

Meat additives are considered the main source of B. cereus contamination in meat products, improper handling of meat products after cooking allow the spores of B. cereus to germinate lead to food poisoning (Torky 2004). 
Bacterial growth results in production of enterotoxins, one of which is highly resistant to heat and acids ( $\mathrm{pH}$ levels between 2 and 11); ingestion leads to two types of illness, diarrheal and emetic (vomiting) syndrome (Ehling- schulz et al. 2004).

Salmonella spp. failed to be detected in grilled kofta, grilled chicken, beef luncheon and chicken luncheon. This is may be due to heat treatment or low level of contamination during processing and may be due to the fact that most pathogenic bacteria are destroyed between $72{ }^{\circ} \mathrm{C}$ to $83{ }^{\circ} \mathrm{C}$.

Regarding to Salmonella spp, Sobieh (2014), Tavakoli and Riazipour (2008) and Moussa et al., (2010) failed to detect Salmonella spp in grilled kofta and grilled chicken, respectively. Moreover, Ahmed and Mohamed (1998) and Gad (2004) Khalifa and Abd El- Shaheed(2005) failed to detect Salmonella spp in beef luncheon and chicken luncheon, respectively .

In the other side, Ghanem (2009) Almutairi (2011), Saad et al., (2011) and Abdel Fattah (2014) found Salmonella spp in grilled kofta by $13.3 \%, 12 \%, 10 \%$ and $33.3 \%$, respectively.

So the presence of Salmonella spp. can be indicate to expecting of cross contamination from raw material to cooked products through contaminated utensils and improper handling.

Therefore, high incidence of food poisoning microorganisms in these products may be due to lack of hygiene in handling and production operation, inadequate storage and post-process contamination (De Sousa et al., 2002).

Preparation of large quantities of meat and chicken meat products and hold for hours without control can facilitate the growth of microorganisms that can contaminate such products from numerous sources during transport, handling, processing, storage and serving (Dawson, 1992).

The current results in table (5) are similar to the results obtained by Zaki (2003) who isolated O44, Al-Mutairi (2011) who isolated serotype O26, Awadallah et al., (2014) also isolated serotypes O26 and O111, Mohammed et al., (2014) could isolate O26:H11 and O111:H2, Moustafa (2015) could isolate O26:H11, O111:H2 and O91:H21, Ahmed (2016) isolated O26:H11 and O111:H2 and Afifi (2017) isolated O26:H11, O111:H4, O125:H21 and O55:H7.

Clinically, EPEC illness is characterized by fever, nausea, vomition, and watery stools, which occasionally contain mucous, but without gross blood (Toledo et. al., 1983). Furthermore, EPEC was implicated in cases of gastroenteritis, cystitis, colitis, pyelonephritis, peritonitis and puerperal sepsis as well as food poisoning outbreaks (Doyle, 1990). Therefore, EPEC showed to be the first bacterial cause of diarrhea in infants and its proportion may reach 54\% (Varnam and Evans, 1991).

Enterotoxigenic E. Coli (ETEC) strains are considered the common cause of traveler's diarrhea and / or children diarrhea and is involved in the production heat labile (LT) and heat stable (ST) enterotoxins (Butler and Clarke, 1994), ETEC may contaminate ready to eat food through a symptomatic carrier, a person who recovers from an ETEC infection and continue to excrete the organism for several months (Cliver, 1990).

On the other hand, EHEC (O111) was implicated in 16 outbreaks of diarrhea in young: children and infants (Evans et al., 1979). Illness caused by EHEC is typically quit severe and characterized by sudden onset 
of sever crampy abdominal pain followed by watery diahrrea which later becomes grossly bloody.

\section{CONCLUSION:}

Overall, the present study allows to conclude that all examined samples were highly contaminated with different bacterial groups as E. coli, S. aureus and B. cereus. In order to improve the sanitary status of meat processing and consequently the quality of meat and chicken products, the following recommendations should be carried out as a good quality raw material, spices and additives should be used in the manufacture of meat and poultry products, because the finished product is substantially influenced by the characteristics of the fresh raw materials, No workers who have infected lesions, Workers should wash their hands thoroughly after using toilet, sneezing, coughing, blowing or picking nose and education and training of the handlers of meat and chicken are the key stones of the effective quality control.

\section{REFERENCES:}

Abdel Fattah, W.M.G. 2014. Incidence of Salmonella and E.coli in ready to eat foods. M.V. Sc. Thesis (Meat hygiene), Fac. Vet. Med., Benha Univ.

Abostate, M.A.M.; Zahran, D.A. and ElHefnawi, H.N. 2006. Incidence of bacillus cereus in some meat products and the effect of gamma radiation on its toxins International Journal of Agriculture and Biology 8 (1): 1-4.

Afifi, M.E.M. 2017. Incidence of some food poisoning microorganisms in ready to eat fast foods Ph.D. Thesis (Meat hygiene), Fac. Vet. Med. Benha Unvi.
Ahmed, A.M. and Mohamed, S.A. 1998. Occurrence of Salmonella and Yesinia Enterocolitica in some meat products. Assuit Vet. Med. J, 38 (78) 29-39.

Ahmed, N.M. 2016. Traceability Diarrheogenic E.coli in meat products with special reference to Enterohemorrhagic Strains. Ph.D, Thesis (Meat Hygiene), Fac.Vet. Med. Benha Unvi

Agunos, A. 2007. Effect of dietary beta 1-4 mannobiose in the prevention of Salmonella enteritidis infection in broilers. British Poultry Science 48 (3), 331-341.

Ali, S.F.H. 2011. Incidence of Enterotoxigenic Staph. aureus in some ready to eat meat sandwiches in Assiut city with special reference to methicillin resistant Staph aureus strains. Assiut. Vet. Med .J, 57 (129): 95-106.

Al-Mutairi, M. F. 2011. The Incidence of Enterobacteriaceae Causing Food Poisoning in Some Meat Products. J. of Food Sci. and Techn, 3(2): 116121.

American Public Health Association "APHA" 2001. Compendium of methods for the microbiological examination of food. $4^{\text {th }}$ Ed Washington D., USA.

Arab, W.S.S. 2010. Quality improvement of meat meals provided by a university student resturant Ph.D. Thesis, Fac. Vet. Med. (Meat hygiene) Benha Univ.

Awadallah, M.A.; Ahmed, H.A. and Merwad, A.M. 2014. Pravalence of Non-O157 shiga toxin-producing E.coli and Enterotoxigenic Global Veterinaria J. 12 (5): 692-699, 2014 . 
Bailey, W. and Scott, E.G. 1998. Diagnostic Microbiology. A text book for the isolation and identification of pathogenic microorganisms. The C.V . Mosby Company Saint Louis.

Butler, D.G. and Clarke, R.C. 1994. Diarrhoea and dysentery in calves. In:C.L. Gyles, Editor, Escherichia coli in Domestic Animals and Humans, Cab Inter., Wallingford p 91-116.

Cliver, D.O. and Marth, E.H.1990. Food borne diseases. $4^{\text {th }}$ Ed. Academic Press Inc. San Diego, USA.

Dawson, R.J. 1992. FAO and street food $3^{\text {rd }}$ world congress food borne infections and intoxications. Vol. 11, 16-19 June, Berlin.

De Sousa, G.B.; Tamagnini, L.M.; Olmos, P.D.; Gonzalez, R.D. 2002. Microbiological enumeration in ready to eat foods and their relationship to good manufacturing practice J.Food Saf 22:27-38.

Doyle, P.M. 1990. Pathogenic E. coli. The Lancet 336: 1111-1115.

Ehling Schulz M.; Fricker, M. and Scherer, S. 2004. Bacillus cereus, the causative agent of an emetic type of food-borne illness. J. of Molecular Nutrition and Food Research, 48(7): 479-487.

Evans, D.G.; Olarte, J.; Dupont, H.L.; Evans, D. J.; Galindo, E.; Portnoy, B.L. and Conklin, $\quad$ R.H. 1979. Enteropathogenic Ecoli associated with pediatric diarrhea in Mexico City. J.Pediatr. 92: 6568

Food and Drug Administration "FDA"2001b. Staphylococcus aureus. Bacteriological analytical manual $.8^{\text {th }}$ Ed. Chapter12. Gaithersburg, 562.
Gad, M.A. 2004. Microbiological evaluation of poultry meat and its products.M.V.Sc., Thesis, Fac. Vet. Med., (Meat hygiene) Sadat branch Minofyia Univ.

Ghanem, S.H.A. 2009. Microbiological status of some ready to eat meat products. M.V.Sc., Thesis (Meat hygiene), Fac. Vet. Med., Benha Univ.

Gundogan, N.; Citak, S.; Yucel, N. and Devren, A. 2005. A note on the incidence and antibiotic resistance of Staph.aureus isolated from meat and chicken samples. Meat Sci., 69(4): 807-810.

Hassanien, F.S. 2004. Bacterial hazards associated with consumption of some meat products. Benha Vet. Med. J., 15(2) $41: 53$

Hassan, M.A.; Nassif, M.Z. and Ibrahim, M.A. 2016. Incidence of staphylococcus aureus in meat products with special refrence to enterotoxins. Benha Vet. Med. J., 30(2): 23-27

Hashim, E.S.Y 2003.Aerabic and anaerobic enterotoxigenic bacteria in ready-toeat food. ph. D.V.Sc., Thesis Meat hygiene, Fac. Vet. Med, Zagazig univ. (Benha branch).

Ibrahim H. M.; Salm, A.M.; Khater, D.F. and Ghanyem, H.R. 2014. Antimicrobial effect of some preservatives on bacillus cereus isolated from some meat products 26 (1): 75-83.

International Commission of Microbiological Specification for Foods "ICMSF" 1996. Microorganisms in Food. ITheir Significance and methods of enumeration. 3rd Ed. Univ. of Toronto, Canada. 
International Organization of Standardization "ISO" 2002. International Organization for Standardization. No.6579. Microbiology of food and animal feeding stuffs - Horizontal methods for detection of salmonella species.

Khalifa, E.M.I and Abd El-Shaheed, Y.T.U. 2005. Bacteriologica1 evaluation of chicken meat and some chicken meat products sold in kafr El-sheikh governorate. $\quad 4^{\text {th }} \quad$ Int. Sci.Conf.,Mansoura.

Kreig, N. and Holt, J. 1984. Bergey's Manual of systemic bacteriologyVol.1.William and Wilkins, Baltimore, M.D.21202, USA.

Kok, T.; Worswich, D. and Gowans, E. 1996. Some serological techniques for microbial and viral infections. In Practical Medical Microbiology (Collee, J; Fraser, A; Marmion, B. and Simmons, A., eds.), $14^{\text {th }}$ Ed., Edinburgh, Churchill Livingstone, UK.

Le Loir, Y.; Baron, F. and Gautier, M. 2003. Staph. aureus and food poisoning Genetics and Molecular Research, 2 (1): 63-76.

Macfaddin, J.F. 2000. Biochemical tests for identification medical bacteria. Warery press, INC. Baltimore, Md. 21202 USA.

Mohammed, A.M.; Sallam, K.I.; Ziad-Eldaly, E.A.; Ahady, M.A. and Tamura, T. 2014. Occurance serotypes and virulence gene of non O157 Shiga toxin-producing E.coli in fresh beef, ground beef and beef burger. Food control 37(2) 182-187.
Morshdy, A.E.M.; El-Atabany, A.I.; Husssein, M.A. and Ibrahim, A.A.E. 2014. Food Poisoning M.Os in Ready to Eat Meat Sandwiches. The 1st International Conference on Impact of Environmental Hazards on Food Safety., Fac. Vet. Med., Zagazig Univ.

Moussa, I.M.; Gassem, M.A.; Al-Doss A.A,; Sadik, M.W.A. and Mawgood, A.L.A. 2010. Using molecular techniques for rapid detection of salmonella serovars in frozen chicken and chicken products collected from Riyadh , Saudi Arabia . Afr. J. of Biotechnol., 9(5): 612-619.

Moustafa, R.R. 2015. Prevalence and Biocontrol of shiga toxin - producing E.coli in some beef products. Ph.D. thesis (Meat hygiene and control). Benha. Unvi

Muth, M.K. 2009. Analysis of Salmonella control performance in US. young chicken slaughter and pork slaughter establishments. J. of Food Prot., 72(1): 6-13.

Rajkovic, A.; Uyttendaele, M.; Courtens, T.; Heyndrickx, M. and Debevere, J. 2006. Prevalence and characterization of Bacillus cereus in vacuum packed potato puree. International J. of Food Sci \& Technol., 41(8): 878-884.

Saad, M.S.; Hemat M.I. and Enas A.M.A. 2011. Microbial and chemical evaluation of fast foods. J. Benha vet. Med. S.E., 1:44-51.

Schoeni, J.L. and Lee Wong, A.C. 2005. Bacillus cereus food poisoning and its toxins. J. Food Prot., 68(3): 636648. 
Shanab, M.S.M. 2014. Quality of some locally manufactured chicken meat products M.V. Sc. Thesis Fac.Vet.Med. (Meat hygiene) Benha Univ.

Sharaf, E.M.; and Sabra, S.M.; 2012. Microbiological loads for some type of cooked chicken meat products at AL-Taif Governorate, K.S.A World Appl. Sci. J.17(5): 593-597.

Shawish, R.R.; Elbagoury, A.M. and Edris, A.M 2014. Conventional and rapid detection of Escherichia Coli in some beef products. Minufiya Vet. J. 8(1): 125-131.

Shinagawa, K. 1990. Analytical methods of Bacillus cereus and other Bacillus species. Int. J. Food Microbiol., 10:125-141.

Sobieh, A.S.A. 2014. Fast meat meals at restaurant level in Cairo Governorate. M. V. Sc. Thesis, Meat Hygiene, Fac. of Vet. Med., Benha Univ.

Synge, B.A. 2000. Verocytotoxin Producing E. coli a veterinary review. J. appl. Microbiol. Symposium Suppl. 88: 315-375.

Tarabees, R.Z.; Hassanin, Z.H and El Bagoury, A.M. 2015. Polymerase Chain Reaction (PCR) An Alternative Rapid Method for Detection of Some Microbial Contamination of Meat Products. AJVS, 45: 91-98

Tavakoli, H.R. and Riazipour M. 2008. Microbial quality of cooked meat foods in Tehran Universities Restaurants. Pak. J. Med Sci. 24(4): 595-599.

Toledo, M.B.F.; Alvariza, M.C.B.; Murahovschi, J.; Sramos, S.R.T. and Trabulsi, L.R. 1983. Enteropathogenic Escherichia coli serotypes and endemic diarrhea in infants. Infect. Immun. 39: 586-589.

Torky A.A.S. 2004. Trials for inhibition of some food poisoning microorganism in meat products. Ph.D Thesis, Meat and Milk Hygiene, Fac. Vet.Med., Cairo Univ.

Varnam, A.H. and Evans, M.G. 1991. Food borne pathogens. An text chapter 13. P 267 England, Wolfe Publishing Ltd. ISBN 07234, 1521,8.

Waldroup, A.L. 1996. Contamination of raw poultry with pathogens. World's Poult. Sci., 52: 7.

Zaki, E.M. 2003. Risk assessment of ready prepared meat products. Ph. D. Thesis, (Meat Hygiene). Fac. Vet. Med., Cairo Univ.

Zhang, L; Davis, MA. and Conner, D.E. 2001. Poultry-borne pathogens: plant considerations. Poultry Meat processing chap.9. ISBN 0 -84930120 -3, CRC Press LLC, New York, USA. 